\title{
IDENTIFYING DESTINATION ATTRACTIVENESS OF KUALA
TERENGGANU PERCEIVED BY DOMESTIC TOURIST
}

\section{Nur Izzati Ab Ghani $^{1+}$ \\ (iD) Muhamad Nasyat \\ Muhamad Nasir ${ }^{2}$ \\ iD Zanariah Mohd \\ Nor ${ }^{3}$ \\ (D) Raja Noor \\ Syuhaida Raja Yahya ${ }^{4}$ \\ Rafazila Ramli ${ }^{5}$ \\ Norhilmi \\ Muhammad $^{6}$ \\ Fazida Karim?}

\author{
${ }^{1,4,6}$ Centre for Fundamental Studies, Universiti Sultan Zainal Abidin, Gong \\ Badak Campus, Kuala Terengganu, Terengganu, Malaysia. \\ 'Email: izzatighani@unisza.edu.my Tel: +60132906558 \\ ${ }^{4}$ Email: syuhaidary@unisza.edu.my Tel: +60129292479 \\ ${ }^{6}$ Email:norhilmimd@unisza.edu.my Tel: +60193603974. \\ ${ }^{2}$ Faculty of Hospitality, Tourism and Wellness, Universiti Malaysia \\ Kelantan, City Campus Pengkalan Chepa, Kota Bharu, Kelantan, Malaysia. \\ ¿Email:nasyat.mn@umk.edu.my.Tel: +60199812570 \\ ${ }^{s}$ Faculty of Bioresources and Food Industry, Universiti Sultan Zainal \\ Abidin, Besut Campus, Besut, Terengganu, Malaysia. \\ ${ }^{3}$ Email:zana@unisza.edu.my Tel: +60133871277 \\ ${ }_{5,7}^{5}$ Faculty of Business and Management, Universiti Sultan Zainal Abidin, \\ Campus Gong Badak, Kuala Terengganu, Terengganu, Malaysia. \\ ${ }^{5}$ Email:rafazila86@gmail.com Tel: +601169341808 \\ Email:fazidakarim@unisza.edu.my Tel: +60193603975

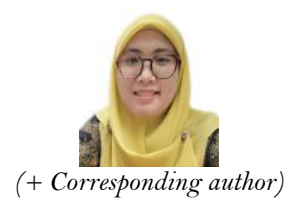 \\ (+ Corresponding author)
}

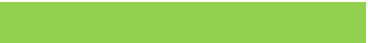

\section{Article History}

Received: 17 June 2021 Revised: 19 July 2021 Accepted: 11 August 2021 Published: 13 September 2021

\section{Keywords}

Destination attractiveness

Kuala terengganu

Domestic tourist

Recreation, leisure and amenities

Accessible

Attraction

Tourism terengganu

EFA

CFA

Discriminant validity.

\section{ABSTRACT}

The mission of Terengganu Tourism Department is to attract and increase tourists so that they will spend on the increased attractiveness and delivery of high-quality services, create an unforgettable experience, and make Terengganu a great destination. However, the last statistics proved that Terengganu is among the states that received a small number of domestic tourists, including tourism receipts, as compared to other states. Terengganu was ranked in the ninth place of visited domestic tourists and receipts in 2018. Therefore, this study aims to identify the underlying factors of destination attractiveness of Kuala Terengganu: assuring that the advertising strategies will use the best strategy which has been formulated to attract the groups of domestics' tourists to visit Kuala Terengganu. Data collection has been carried out using a Google Forms online questionnaire. A total of 90 respondents who had experience visiting Kuala Terengganu were involved in this study. The method of Exploratory Factor Analysis (EFA) and Confirmatory Factor Analysis (CFA) divided destination attractiveness construct into three factors namely 1) recreation, leisure and amenities; 2) accessible and; 3) attractions. The findings of this study are very useful to marketing practitioners in designing promotional campaigns of destination attractiveness towards Kuala Terengganu.

Contribution/ Originality: This study contributes to the existing literature on destination attractiveness in the tourism industry. The findings revealed, destination attractiveness personified by recreation, leisure and amenities, infrastructures and attractiveness enable Kuala Terengganu to distinguish itself from other competing destinations in Malaysia.

\section{INTRODUCTION}

Domestic tourists have generally proven essential to the survival of many countries' tourism sectors, and this holds true for Malaysia as well. Ever since Malaysia is focusing on the arrival of international visitors, the Malaysia 
Tourism Ministry (a.k.a Malaysian Ministry of Culture, Arts and Tourism, MOCAT) acknowledged that domestic tourism receipts are rising at an estimated 15\% annually. In 2018, a total of 221.3 million domestic visitors were recorded, an increase of 7.7 percent over the previous year (Department of Statistic Malaysia, 2019). Domestic visitors made 302.4 million visits within the country in terms of total tourism visits. Domestic tourism expenditure has continued to register a double-digit growth with 11.4 percent in 2018 compared to the previous year, which recorded a growth rate of 11.1 percent (Department of Statistic Malaysia, 2019). Tourism Malaysia (2018) argued that domestic tourism remained a pivotal contributor to the local economy and it is promoted through travel fairs, travel marts, and smart partnerships. Aligned with the role of Tourism Malaysia in promoting the growth of domestic tourism, the Ministry must understand the needs of domestic tourists to formulate specific and strategic promotions of destinations (Tourism Malaysia, 2018). Acknowledging the remarkable performance and prospects of domestic tourism, every state in Malaysia promotes its tourism products attractively, thus increasing domestic tourists visits. These initiatives are geared toward facilitating and supporting the local economy of the states.

The well-known riverine city in District of Kuala Terengganu is located at the estuary of Terengganu River. For decades, Kuala Terengganu used to be the main port for those who are doing trading, exchanging the knowledge and also as a transit for sailors from the nearby region; including from other parts of the world. As a waterfront city with the mixed of historical buildings, Kuala Terengganu has been chosen as a main attraction for tourism as well as a corridor for investors. For Kuala Terengganu has thousands of fascinating places and attractions, where people will find the uniqueness of life; mixing with local tradition and urban lifestyle, people will be blended in rich cultures, heritage, beauty of nature, and the warmth of its people; all together in the developing city of Kuala Terengganu. The Terengganu State Economic Planning (2008) believed that the tourism industry is set to become one of the major contributors to Terengganu's gross domestic product and positioned the industry as the second most important economic sector after the petroleum and gas industry. The mission of Terengganu Tourism Department is to attract and increase tourists so that they will spend on the increased attractiveness and delivery of high-quality services, create an unforgettable experience, and make Terengganu a great destination. Terengganu Tourism Department claimed that by 2025, the state aims to attract 6.5 million tourists which would generate about RM6 billion in total in tourist receipts. According to the Department of Statistic Malaysia (2019), the top five states receiving the most domestic tourists and tourism receipts in 2018 were Selangor (30.2 million visitors), Sabah (20.4 million), Sarawak (19.4 million), W.P. Kuala Lumpur (19.2 million), and Pahang (18.1 million). Unfortunately, Terengganu was among the states that received a smaller number of domestic tourists (refer to Figure 1). Terengganu ranked in the ninth place of visited domestic tourists in 2018. Therefore, it is important to study on destination attractiveness since it builds a tourist's personal positive connection, where visitors value the experience at the destination and become a competitive advantage to the destination (Mohamad, Nasir, Ab Ghani, \& Afthanorhan, 2019). In other words, without attraction, tourism is impossible. Most of the tourism destinations are bound to enhance their attractiveness in order to boost tourism receipts, government and employment revenues (Ramseook-Munhurrun, Seebaluck, \& Naidoo, 2015). Therefore, the aim of this study is to identify destination attractiveness of Kuala Terengganu as perceived by domestic tourists. This is very useful to marketing practitioners in designing promotional campaign of destination attractiveness.

\section{LITERATURE REVIEW}

\subsection{Destination Attractiveness}

According to $\mathrm{Hu}$ and Ritchie (1993), the term "destination attractiveness" refers to an individual's feelings, beliefs, and opinions about a destination's perceived ability to satisfy his or her unique vacation needs. This definition denotes that destination attractiveness comprises of cognitive and affective evaluations of tourists on the destination's offerings during their holiday Hu and Ritchie (1993). 


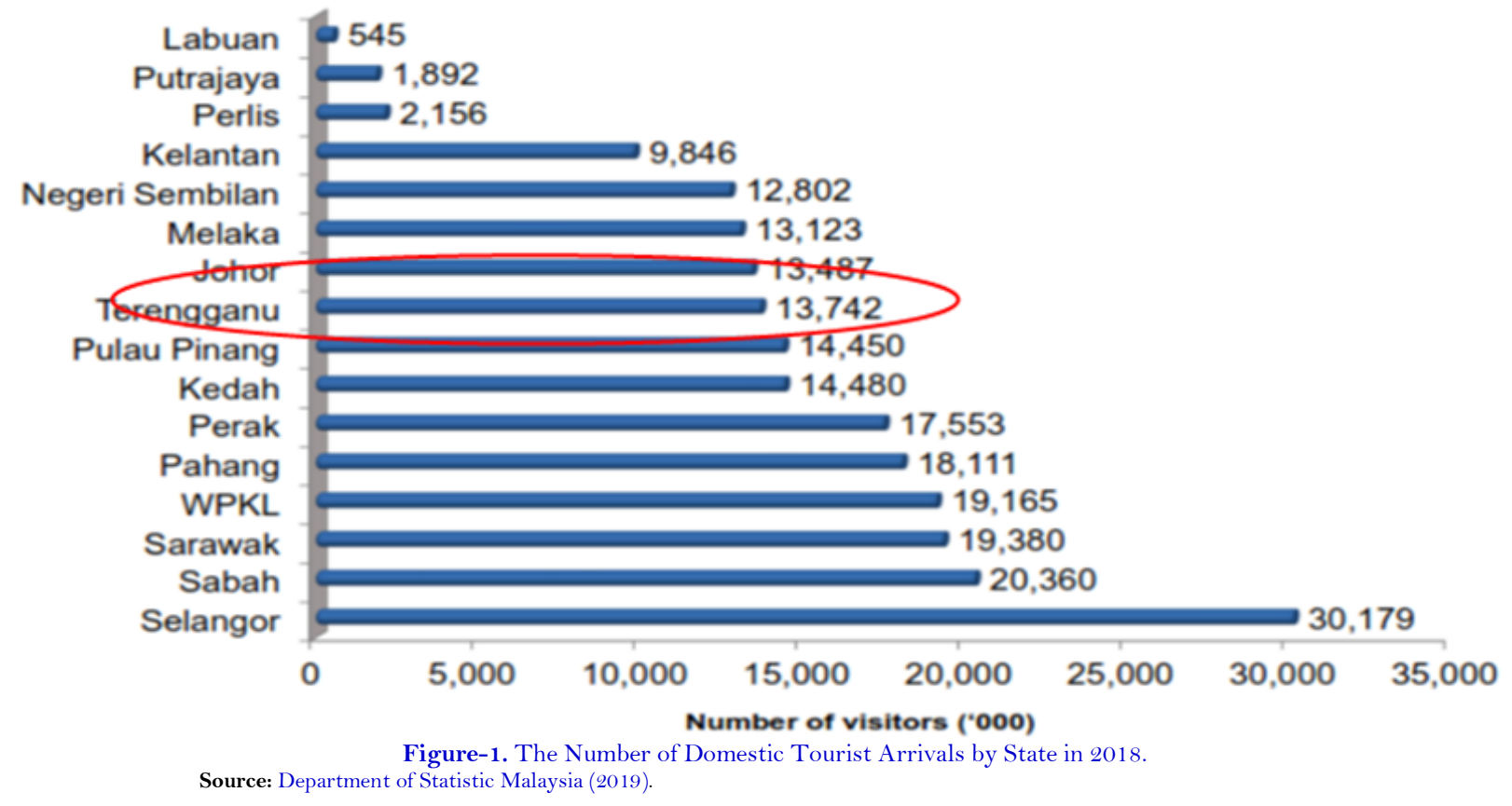

On the other hand, Krešić and Prebežac (2011) contended that destination attractiveness is inextricably linked to destination image analysis, as the concepts of destination image and destination attractiveness are conceptually linked. As a result, the appeal of a destination is largely determined by its image, and vice versa. Meanwhile, Ariya, Wishitemi, and Sitati (2017) claimed that destination attractiveness is frequently illustrated with the features or attributes of a specific destination. Features or attributes of a specific destination refer to natural attribute (such as beaches, forests, and animals) and man-made attribute (like resorts, theme parks, and restaurants) (Ariya et al., 2017). Hence, this study adopted destination attractiveness as cognitive and affective evaluations of tourists on natural attribute and man-made attribute that destination could provide to satisfy tourist's vacation needs.

According to Buhalis (2000), destination attractiveness is defined as areas or geographical areas that provide a combination of tourism products and services with tangible and administrative boundaries that define their management, images, and perceptions of market competitiveness. Buhalis (2000) further described that the aspect comprises the entire range of facilities and services offered locally, together with all socio-cultural, environmental resources and public goods. According to Kresic (2008) attractiveness is defined as 'those characteristics of a tourism destination that, by their unique characteristics, attract or encourage tourists to attend.' Similarly, Cho (2008) explained that attractiveness 'is an aggregated indicator of attributes that make a specific location appealing as a potential destination to travellers'. 3

Based on the above literature review on tourism destination attractiveness, this study conceptualized destination attributes as meeting the tourists' needs and goals. This is further derived from the declaration that the shortage in the literature is still the need to identify what sector-specific attributes influence people towards a particular tourist activity and further lead them to choose one destination over another (Nasir, Mohamad, Ghani, \& Afthanorhan, 2020). Recent studies revealed differences and similarities in features or attributes of destinations. For instance, Chaudhary and Islam (2020) study identified nine attributes of destination namely cultural attractions, tourist activity, transport facilities, hygiene and cleanliness, food attractions, natural attractions, accommodation facilities, cost, and tourists amenities need to be considered in order to evaluate the attractiveness of the destination. However, Nasir et al. (2020) only delineated two attributes of destination in their study, specifically cultural attractiveness and infrastructures. Raimkulov, Juraturgunov, and Ahn (2021) study also identified two similar attributes as Nasir et al. (2020), and they further added natural attractiveness, local people and superstructure, and price attractiveness to the destination features. The presented differences and similarities of attributes of a 
particular destination may be explained by local specific differences in terms of destination administration, sociocultural, environmental resources and services.

\section{RESEARCH METHODOLOGY}

This study employed a quantitative research design. The unit of analysis for this study was the individual level. The study population was domestic tourists in Kuala Terengganu. This study used the definition of domestic tourist as per (UKM Report, 1999), i.e. "any person residing in Malaysia regardless of his/her nationality who travels to a place at least 40 kilometres away (one way) from his/her usual place of residence for at least one night or less than one night for any reason other than following an activity remunerated at the place visited". Nonprobability with a purposive sampling method was used to identify the study's respondents. The selection criteria of the study was domestic tourists who had experience visiting Kuala Terengganu.

A total of 90 respondents participated in this study through Google Forms, an online survey administration software used for data collection. The development of destination attractiveness was adapted from Islam, Hossain, and Noor (2017). The survey's list of 41 items measures a destination's attractiveness. Respondents must rate their level of agreement with the statements using a seven-point Likert scale ranging from 1 to 7 , with 1 indicating strong disagreement and 7 indicating strong agreement. With the goal of reducing and summarising the items of destination attractiveness, the acquired data was analysed using Exploratory Factor Analysis from the Statistical Package for Social Science programme (SPSS version 23). Reliability analysis was also performed to test reliability and validity of the study instrument.

\section{RESULTS}

\subsection{Respondent's Profile}

The study findings revealed that most domestic tourists in Kuala Terengganu originated from Negeri Sembilan $(33.3 \%)$ and Selangor (32.2\%). Majority of them were married $(92.2 \%)$, female $(63.3 \%)$, and represented the age group of 32 to 52 years old and above (52.3\%). In addition, majority (62.2\%) indicated that they visited Kuala Terengganu more than 5 times. About 75 percent of them purposively visited Kuala Terengganu for holidays. On average, most domestic tourists (40.0\%) spent at least three days and almost all (90.0\%) spent about RM101 - RM 1600 mainly on food and beverage as well as local shopping (83.3\%). During they visit to Kuala Terengganu, majority of them $(51.1 \%)$ chose to stay at hotels than other types of accommodations.

\subsection{Exploratory Factor Analysis on Attractiveness of Kuala Terengganu}

Exploratory Factor Analysis (EFA) function is to describe and summarize the data by grouping together the variables that are correlated (Zikmund \& Babib, 2010). After conducting the study's pilot test, EFA was conducted to generate the underlying dimensions of destination attractiveness of Kuala Terengganu. Several conditions were taken into consideration prior to the conduct of EFA on the study data set. First, the value of Kaiser-Meyer-Olkin (KMO) Measure of Sampling Adequacy (MSA) should be greater than 0.50 (Hair, Black, Babin, \& Anderson, 2014a). Second, Bartlett's test of Sphericity results should be significant at $\mathrm{p}<0.001$ as suggested by Hair et al. (2014a). Third, the extraction of factors in EFA was examined using principal component analysis to identify the number of factors to be retained while Varimax rotation was applied as it is the most popular, and orthogonal factor rotation method was performed to clarify the analysis of factors (Hair et al., 2014a). Fourth, as suggested by Hair et al. (2014a) the items with factor loadings of absolute value below than \pm 0.5 were discarded whilst those with greater value than \pm 0.55 were considered necessary to be measured; thus retained. Table 1 depicts the guidelines for identifying factor loadings based on sample size as proposed by Hair et al. (2014a).The scale loading with eigenvalues of 1 and above was used. Furthermore, as suggested by Hair et al. (2014a), the variance explained must 
be higher than the recommended point of 60 percent. Therefore, the current study primarily relied on this recommendation in order to conduct EFA.

Table-1. Sample size identification guideline for factor loading.

\begin{tabular}{c|c}
\hline Factor loading & Required sample size for significance \\
\hline 0.30 & 350 \\
\hline 0.35 & 250 \\
\hline 0.40 & 200 \\
\hline 0.45 & 150 \\
\hline 0.50 & 120 \\
\hline 0.55 & 100 \\
\hline $\mathbf{0 . 6 0}$ & $\mathbf{8 5}$ \\
\hline 0.65 & 70 \\
\hline 0.70 & 60 \\
\hline 0.75 & 50 \\
\hline Source: Hair et al. (2014a). &
\end{tabular}

Table 2 indicates the result of KMO and Bartlett's test of sphericity for destination attractiveness. The value of KMO was higher than 0.5 and the Bartlett's test of sphericity result was significant $(\mathrm{p}<0.001)$ which met the standard as suggested by Hair et al. (2014a). Therefore, the variable of destination attractiveness was appropriate for EFA.

Table-2. Result of examination of construct (Destination attractiveness) for exploratory factor analysis suitability.

\begin{tabular}{l|l|r}
\hline \multicolumn{2}{l}{ KMO and Bartlett's Test } \\
\hline \multicolumn{2}{l}{ Kaiser-Meyer-Olkin Measure of Sampling Adequacy. } & 0.924 \\
\hline Bartlett's Test of Sphericity & Approx. Chi-Square & 2640.197 \\
\cline { 2 - 3 } & df & 300 \\
\cline { 2 - 3 } & Sig. & 0.000 \\
\hline
\end{tabular}

Forty items were initially selected to measure destination attractiveness. After EFA was performed, 25 items remained with factor loading higher than 0.60. Table 3 summarizes the EFA result on destination attractiveness. Three dimensions were extracted which accounted for 74 percent of the total variance and eigenvalues with each dimension ranged between 1.440 and 15.980, which were above than 1 as suggested by Hair et al. (2014a). What was the underlying structure of destination attractiveness as perceived by the domestic tourists of Kuala Terengganu? As shown in Table 3, the EFA results demonstrated that three factors had eigenvalues exceeding the Kaiser criterion of 1.0, precisely, Factor 1 (15.98), Factor 2 (7.36) and Factor 3 (1.44). This three-factor solution explained 74.00 percent of the variance in the domestic tourists' perceived destination attractiveness. Factor 1 contributed the highest variance of 35.8 percent, followed by Factor 2 with about 21.30 percent, while Factor 3 contributed the least variance with about 16.90 percent.

A total of 15 items on recreation, leisure and amenities were clustered into Factor 1 . The highest factor loading of Factor 1 was 0.800 , whereas the lowest was 0.603 . The top five items with strong loadings above 0.750 suggested that this factor was measured best based on the variety and diverse tourism activities available in the city. 'Varieties of water sports' (D38: $\left.\mathrm{h}^{2}=0.800\right)$, 'exciting nightlife' (D34: $\left.\mathrm{h}^{2}=0.786\right)$, 'varieties of festivals and special events' (D36: $\left.\mathrm{h}^{2}=0.785\right)$, 'reasonable price of local handicraft products' (D29: $\mathrm{h}^{2}=0.763$ ) and 'opportunities to visit friends and relatives' $\left(\mathrm{D} 35: \mathrm{h}^{2}=0.763\right)$ were the top five items measuring Factor 1. With relatively lower factor loadings of lesser than 0.750 , Factor 1 was also explained by ten items which included gauging hygiene and cleanliness, costing, accommodation facilities and food attractions in the city. In a descending order of factor loading values, 'pleasant weather and good environment' (D33:h²=0.734), 'discounted tourism packages' $\left(\mathrm{D} 30: \mathrm{h}^{2}=0.724\right)$, 'clean city and preserved environment' (D32: $\left.\mathrm{h}^{2}=0.723\right)$, 'fresh and clear air' (D31: $\left.\mathrm{h}^{2}=0.687\right)$, 'sport opportunities' (D32:h²=0.686), 'well-decorated, comfortable and good quality of accommodations' (D23: $\mathrm{h}^{2}=0.683$; 
$\left.\mathrm{D} 40: \mathrm{h}^{2}=0.650\right)$ and finally, 'variety of food and beverages in restaurant's $\left(\mathrm{D} 39: \mathrm{h}^{2}=0.603\right)$ explained the parts of Factor 1. Reflecting on the conceptual meaning of the 15 items, it illustrates the vacation needs of the domestic tourists; thus, Factor 1 was named as 'Recreation, leisure and amenities'.

Factor 2 was named as 'Accessibility' which was illustrated by six items. This factor was dominantly characterized by four items related to accessibility with loadings ranged from 0.8 to 0.7 that specifically involved 'ATM services' (D15: $\left.\mathrm{h}^{2}=0.805\right)$, 'Kuala Terengganu city’ (D19: $\left.\mathrm{h}^{2}=0.798\right)$, 'public transportations' $\left(\mathrm{D} 18: \mathrm{h}^{2}=0.771\right)$, 'transportation services' and 'local travel information' (D17: $\left.\mathrm{h}^{2}=0.733\right)$. Good shopping store facilities in the city $\left(\mathrm{D} 25: \mathrm{h}^{2}=0.650\right)$ also explained 'Accessibility' but with the lowest factor loading.

Factor 3 was characterized by four items with factor loadings ranged from 0.7 to 0.6. The top three identical items measuring this factor were associated with the varieties of local attractions, specifically 'Islamic tourist attractions' (D5: $\left.\mathrm{h}^{2}=0.767\right)$, 'cultural attractions' $\left(\mathrm{D} 6: \mathrm{h}^{2}=0.764\right)$, and 'natural attractions' $\left(\mathrm{D} 7: \mathrm{h}^{2}=0.759\right)$. The iconic Terengganu drawbridge as the newest local attraction also explained Factor 4 but with a relatively lower factor loading $\left(\mathrm{D} 1: \mathrm{h}^{2}=0.666\right)$. Reflecting on the conceptual level of the items on local attractions, therefore, Factor 3 was named as 'Attractions'.

Table-3. EFA: Item retained in destination attractiveness.

\begin{tabular}{|c|c|c|c|c|}
\hline No. & Items & $\begin{array}{l}\text { Factor } \\
\text { Loading }\end{array}$ & $\begin{array}{l}\text { Eigen } \\
\text { Value }\end{array}$ & $\begin{array}{l}\text { Total Variance } \\
\text { Explained (\%) }\end{array}$ \\
\hline & & & & 74.008 \\
\hline & Factor 1: Recreation, Leisure and Amenities & & 15.980 & 35.813 \\
\hline 1 & There are varieties of water sports offered (D38) & 0.800 & & \\
\hline 2 & Exciting nightlife with endless entertainment in the city (D34) & 0.786 & & \\
\hline 3 & Variety of festivals as well as special events around the city (D36) & 0.785 & & \\
\hline 4 & Reasonable price of local handicraft products (D29) & 0.763 & & \\
\hline 5 & Opportunity to visit friends and relatives during the stay (D35) & 0.763 & & \\
\hline 6 & Pleasant weather and good environment during the stay (D33) & 0.734 & & \\
\hline 7 & Discounted tourism packages offered throughout the year (D30) & 0.724 & & \\
\hline 8 & The city has a clean and preserved environment (D32) & 0.723 & & \\
\hline 9 & Local products are cheaper than in other places (D28) & 0.715 & & \\
\hline 10 & The air in the city is fresh and clear (D31) & 0.687 & & \\
\hline 11 & Sports opportunities can be accessed in the city (D37) & 0.686 & & \\
\hline 12 & $\begin{array}{l}\text { Well-decorated and comfortable accommodations in all properties } \\
\text { (D23) }\end{array}$ & 0.683 & & \\
\hline 13 & Good quality of accommodation offered in the city (D26) & 0.667 & & \\
\hline 14 & Good quality and appetizing foods and beverages are offered (D40) & 0.650 & & \\
\hline \multirow[t]{2}{*}{15} & Variety of food and beverages are offered in restaurants (D39) & 0.603 & & \\
\hline & Factor 2: Accessible & & 7.364 & 21.299 \\
\hline 1 & ATM services are easy to be found (D15) & 0.805 & & \\
\hline 2 & The city of Kuala Terengganu is easily accessible (D19) & 0.798 & & \\
\hline 3 & Public transportations are easily available (D18) & 0.771 & & \\
\hline 4 & The transportation services are easily booked (D20) & 0.761 & & \\
\hline 5 & Local travel information is easily available (D17) & 0.733 & & \\
\hline \multirow[t]{2}{*}{6} & Good shopping store facilities in the city (D25) & 0.650 & & \\
\hline & Factor 3: Attractions & & 1.440 & 16.895 \\
\hline 1 & $\begin{array}{l}\text { Islamic tourist attractions [e.g.: The Islamic Civilization Park } \\
\text { (TTI) \& Tengku Tengah Zaharah Mosque (known as Floating } \\
\text { Mosque)] (D5) }\end{array}$ & 0.767 & & \\
\hline 2 & $\begin{array}{l}\text { Variety of cultural attractions (ex. China Town, Noor Arfa Craft } \\
\text { Complex \& Kota Duyong) (D6) }\end{array}$ & 0.764 & & \\
\hline 3 & $\begin{array}{l}\text { Variety of natural attractions (ex. Batu Buruk Beach, Pantai Teluk } \\
\text { Ketapang Beach, Tok Jembal Beach \& Marang River Estuary) (D7) }\end{array}$ & 0.759 & & \\
\hline 4 & The iconic Terengganu drawbridge is amazing (D1) & 0.666 & & \\
\hline
\end{tabular}

\subsection{Reliability Test}

Following EFA operation, an internal consistency reliability analysis of destination attractiveness was undertaken. Cronbach's alpha coefficient value for destination attractiveness was 0.976 , which was greater than 0.7. 
This meant that the 25 items pertaining to destination attractiveness were possibly free of random error and thus qualified for the actual survey.

\subsection{Confirmatory Factor Analysis (CFA)}

After conducting EFA, CFA was employed to validate the measurement model (Hair, Gabriel, \& Patel, 2014). The EFA result would include the underlying factors that most accurately reflect the data, as well as their associated measurement items. Following EFA, CFA was used to determine the variables' goodness-of-fit to the study construct. As recommended by the literature, any measuring items with factor loadings less than 0.6 and squared multiple correlations (R2) less than 0.4 should be excluded from the analysis (Awang, 2015). The measurement model for destination attractiveness is depicted in Figure 2. Following the item deletion process, several items were eliminated, leaving 16 items with three factors that define a more fit model.

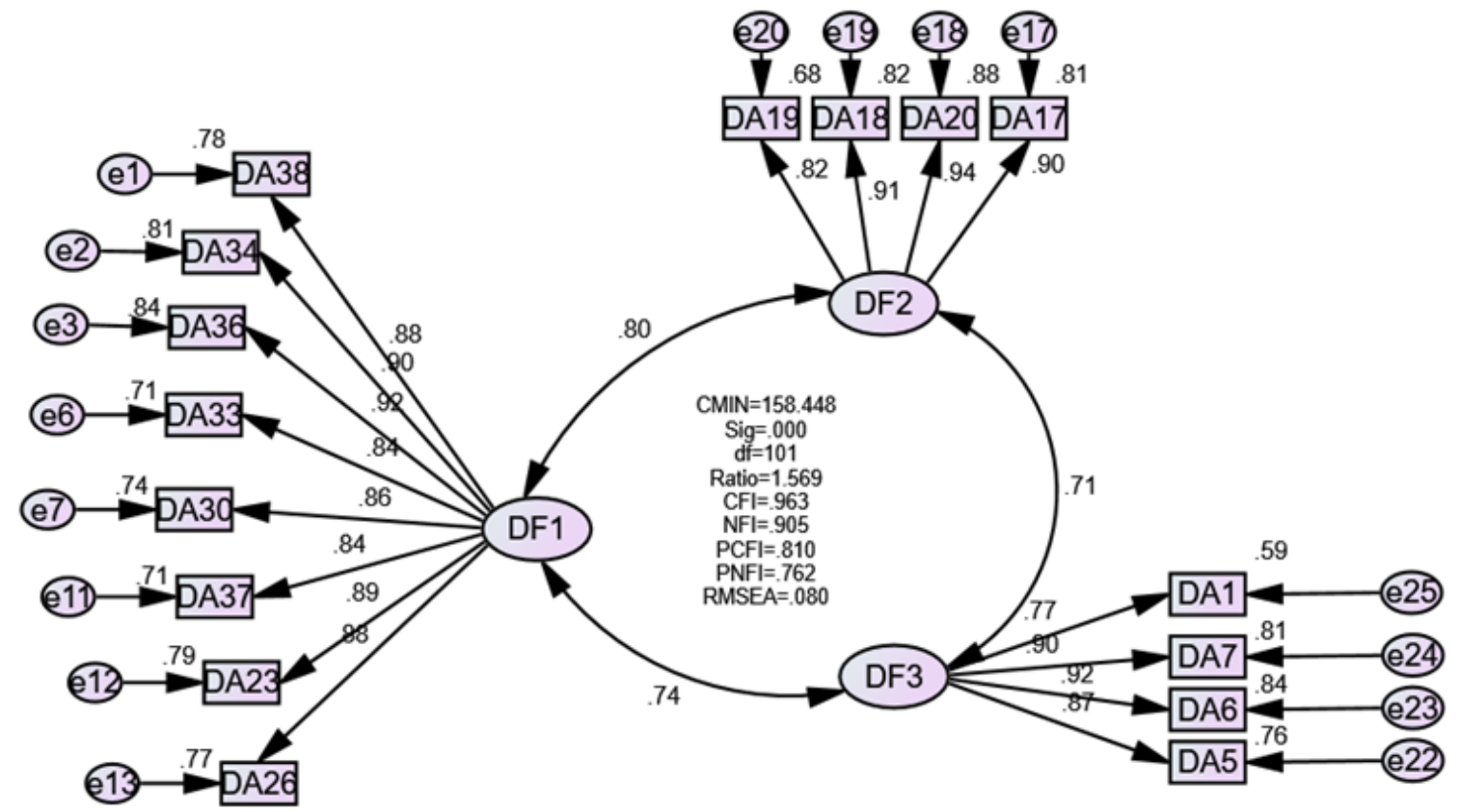

Figure-2. Measurement Model of Destination Attractiveness - Consists of 16 items.

The fitness indices for the measurement model of destination attractiveness for domestic tourists are shown in Table 4. The RMSEA was one of the indicators used as a reference in this analysis. The RMSEA value in this model was 0.08, indicating a better fit. CFI and NFI results provided better estimate of 0.963 and 0.905 respectively, which were similar to Hair et al. (2014) suggested for model fit. The normed chi-square value was less than 3.0, indicating a more fitted model (Hair et al., 2014).

Table-4. Goodness-of-fit indices for the measurement model of destination attractiveness.

\begin{tabular}{c|c|c|c|c|c}
\hline $\begin{array}{c}\text { Total No. of } \\
\text { Items }\end{array}$ & $\begin{array}{c}\text { No. of Items } \\
\text { Remaining }\end{array}$ & $\begin{array}{c}\text { RMSEA } \\
(=\mathbf{0 . 0 8})\end{array}$ & $\begin{array}{c}\text { CFI } \\
(=\mathbf{0 . 9 0})\end{array}$ & $\begin{array}{c}\text { NFI } \\
(=\mathbf{0 . 9 0})\end{array}$ & $\begin{array}{c}\text { Chi- } \\
\text { square/df }\end{array}$ \\
\hline 25 & 16 & 0.08 & 0.963 & 0.905 & 1.569 \\
\hline
\end{tabular}

It is critical to assess the measuring model of destination attractiveness' one-dimensionality, validity, and reliability. The standardised factor loadings of each factor in the measurement model were used to assess unidimensionality (Awang, 2015; Hair et al., 2014). The standardised factor loading values of variables for destination attractiveness exceeded the cut-off point of 0.6, suggesting that the constructs achieved the unidimensionality requirement. The reliability of the measurement model was ascertained by examining composite 
reliability (CR). Composite reliability (CR) measured the reliability and internal consistency of the variable which required a value $=0.6$ to achieve composite reliability (Hair et al., 2014). Meanwhile, the measurement validity was tested using convergent validity and discriminant validity. Convergent validity was achieved by looking at the value of Average Variance Extracted (AVE). The AVE value of above 0.5 was considered acceptable in achieving adequate convergent validity (Hair et al., 2014). The values of AVE and CR in Table 5 suggested that the model achieved the acceptable level of validity and reliability since AVE and CR values surpassed the acceptable cut-off point of 0.5 and 0.6 , respectively.

Table-5. Test of validity and reliability for destination attractiveness measurement model.

\begin{tabular}{|c|c|c|c|}
\hline Construct/Items & Factor Loading & $\mathbf{C R}$ & AVE \\
\hline Factor 1: Recreation, Leisure and Amenities & & 0.961 & 0.756 \\
\hline There are varieties of water sports offered (D38) & 0.88 & & \\
\hline Exciting nightlife with endless entertainment in the city (D34) & 0.90 & & \\
\hline Variety of festivals as well as special events around the city (D36) & 0.92 & & \\
\hline Pleasant weather and good environment during the stay (D33) & 0.84 & & \\
\hline Discounted tourism packages offered throughout the year (D30) & 0.86 & & \\
\hline Sports opportunities can be accessed in the city (D37) & 0.84 & & \\
\hline Well-decorated and comfortable accommodations in all properties (D23) & 089 & & \\
\hline Good quality of accommodation offered in the city (D26) & 0.88 & & \\
\hline Factor 2: Accessible & & 0.950 & 0.992 \\
\hline The city of Kuala Terengganu is easily accessible (D19) & 0.82 & & \\
\hline Public transportations are easily available (D18) & 0.91 & & \\
\hline The transportation services are easily booked (D20) & 0.94 & & \\
\hline Local travel information is easily available (D17) & 0.90 & & \\
\hline Factor 3: Attractions & & 0.923 & 0.752 \\
\hline $\begin{array}{l}\text { Islamic tourist attractions [e.g.: The Islamic Civilization Park (TTI) \& } \\
\text { Tengku Tengah Zaharah Mosque (known as Floating Mosque)] (D5) }\end{array}$ & 0.87 & & \\
\hline $\begin{array}{l}\text { Variety of cultural attractions (ex. China Town, Noor Arfa Craft Complex \& } \\
\text { Kota Duyong) (D6) }\end{array}$ & 0.92 & & \\
\hline $\begin{array}{l}\text { Variety of natural attractions (ex. Batu Buruk Beach, Pantai Teluk Ketapang } \\
\text { Beach, Tok Jembal Beach \& Marang River Estuary) (D7) }\end{array}$ & 0.90 & & \\
\hline The iconic Terengganu drawbridge is amazing (D1) & 0.77 & & \\
\hline
\end{tabular}

The requirement of discriminant validity was satisfied by examining the value of the correlation between two variables and the square root of AVE of the variables (Hair et al., 2014). Table 6 suggests that all the variables between amenities, infrastructure and attractiveness in this study achieved the discriminant validity requirement. The values of square root of the average variance extracted from each variable (diagonal values in bold) were higher than the values of the correlation between each variable.

Table-6. The discriminant validity index summary.

\begin{tabular}{c|c|c|c}
\hline & Amenities & Infrastructure & Attractiveness \\
\hline Amenities & 0.86 & & \\
\hline Infrastructure & 0.80 & 0.99 & \\
\hline Attractiveness & 0.74 & 0.71 & 0.86 \\
\hline
\end{tabular}

\section{CONCLUSIONS}

Destination attractiveness is a critical factor in the tourism industry's success. This factor contributes significantly to the creation of a suitable and acceptable image for potential tourists. The data from this study has uncovered the underlying structures that may affect the domestics tourist in choosing their destination place. The domestic tourists participated in this study characterized destination attractiveness of Kuala Terengganu by three factors namely, 1) recreation, leisure and amenities; 2) accessible and 3) attractiveness. In summary, these domestic 
tourists perceived Kuala Terengganu offered them amenities that were dominantly characterized by a variety of choices of tourism activities (festivals, water sports, tourism package), good quality and comfortable amenities of accommodation. Simultaneously, their perceived amenities were highly associated with conducive infrastructure mainly characterized by ease in accessing local transportation services and travel information. The local tourists also perceived that Kuala Terengganu has varieties of attractiveness that are mainly described by cultural and natural attractions, followed by Islamic tourists attractions and finally the new iconic Terengganu drawbridge.

Based on the study's findings, destination attractiveness personified by recreation, leisure and amenities, infrastructures and attractiveness enable Kuala Terengganu to distinguish itself from other competing destinations in Malaysia. Therefore, Terengganu's brand image can be established after conducting thorough research from tourists' perspectives. The study's findings will help the Tourism Terengganu agency strategically enhance the unique local characteristics that are meaningful to the domestic tourists. The study's findings were in contrast with the overseas studies that suggested different target markets require different marketing strategies. As such, Tourism Terengganu can design suitable promotional strategies by highlighting the positive destination attractiveness of Kuala Terengganu which are more appealing to the cognitive and affective evaluations of domestic tourists (Ariya et al., 2017). Therefore, they will be most likely inclined to select Kuala Terengganu as their travel destination endless times.

\section{LIMITATION AND RECOMMENDATION}

This study was conducted not without limitations and these limitations should be addressed in future studies. The first limitation was the study location. This study only focused on identifying the destination attractiveness of Kuala Terengganu. Therefore, future study should focus on the Terengganu state as a whole to capture the wholistic image of the state as perceived by domestic tourists. Second, a neighbouring city in the east coast of Peninsular Malaysia, specifically Kota Bharu, Kelantan should be included as a comparison capital city to verify perceived destination attractiveness of Kuala Terengganu. Third, this study was conducted during Covid-19 pandemic, thus the data were derived through online google form among domestic tourists who had experience visiting Kuala Terengganu. Future research undertaking should conduct similar study via face-to-face at the tourism spots of Kuala Terengganu to secure more impactful perception on destination attractiveness of Kuala Terengganu.

Funding: This study was funded under Dana Penyelidikan Universiti (R0257), Universiti Sultan Zainal Abidin, Malaysia.

Competing Interests: The authors declare that they have no competing interests.

Acknowledgement: All authors contributed equally to the conception and design of the study.

\section{REFERENCES}

Ariya, G., Wishitemi, B., \& Sitati, N. (2017). Tourism destination attractiveness as perceived by tourists visiting Lake Nakuru National Park, Kenya. International Journal of Research in Tourism and Hospitality, 3(4), 1-13.

Awang, Z. (2015). SEM made simple: A gentle approach to learning structural equation modeling. Malaysia: MPWS Rich Publication. Buhalis, D. (2000). Marketing the competitive destination of the future. Tourism Management, 21(1), 97-116.

Chaudhary, M., \& Islam, N. U. (2020). Influence of destination attractiveness on tourist satisfaction and future travel inten tions: A study of Kashmir valley. Journal of Tourism, 21(1), 13-28.

Cho, V. (2008). Linking location attractiveness and tourist intention. Tourism and Hospitality Research, 8(3), 220-224. Available at: https://doi.org/10.1057/thr.2008.20.

Department of Statistic Malaysia. (2019). My local states terengganu 2018. Malaysia: Department of Statistics.

Hair, J. F., Black, W. C., Babin, B. J., \& Anderson, R. E. (2014a). Multivariate data analysis (7th ed.). United States: Pearson Education Limited. 
Hair, J. F., Gabriel, M., \& Patel, V. (2014). AMOS covariance-based structural equation modeling (CB-SEM): Guidelines on its application as a marketing research tool. Brazilian Journal of Marketing, 13(2), 44-55.

Hu, Y., \& Ritchie, J. B. (1993). Measuring destination attractiveness: A contextual approach. Journal of Travel Research, 32(2), 2534. Available at: https://doi.org/10.1177/004728759303200204.

Islam, S., Hossain, M. K., \& Noor, M. E. (2017). Determining drivers of destination attractiveness: The Case of nature-based tourism of Bangladesh. International Journal of Marketing Studies, 9(3), 10-23. Available at: https://doi.org/10.5539/ijms.v9n3p10.

Kresic, D. (2008). Index of destination attractiveness (IDA): A tool for measuring attractiveness of tourism destination. In An Enterprise Odyssey. Paper presented at the International Conference Proceedings. University of Zagreb, Faculty of Economics and Business.

Krešić, D., \& Prebežac, D. (2011). Index of destination attractiveness as a tool for destination attractiveness assessment. Tourism: An International Interdisciplinary Journal, 59(4), 497-517.

Mohamad, M., Nasir, M. N. M., Ab Ghani, N. I., \& Afthanorhan, A. (2019). Parallel mediators of place attachment and tourist satisfaction in destination attractiveness, destination loyalty and service quality. International Journal of Innovation, Creativity and Change, 7(7), 228-256.

Nasir, M., Mohamad, M., Ghani, N., \& Afthanorhan, A. (2020). Testing mediation roles of place attachment and tourist satisfaction on destination attractiveness and destination loyalty relationship using phantom approach. Management Science Letters, 1O(2), 443-454. Available at: https://doi.org/10.5267/j.msl.2019.8.026.

Raimkulov, M., Juraturgunov, H., \& Ahn, Y.-j. (2021). Destination attractiveness and memorable travel experiences in silk road tourism in Uzbekistan. Sustainability, 13(4), 2252. Available at: https://doi.org/10.3390/su13042252.

Ramseook-Munhurrun, P., Seebaluck, V. N., \& Naidoo, P. (2015). Examining the structural relationships of destination image, perceived value, tourist satisfaction and loyalty: Case of Mauritius. Procedia-Social and Behavioral Sciences, 175, 252-259. Available at: https://doi.org/10.1016/j.sbspro.2015.01.1198.

Terengganu State Economic Planning. (2008). Annual report. Kuala Terengganu, Syarikat Percetakan Yayasan Islam Terengganu Sdn. Bhd, Terengganu.

Tourism Malaysia. (2018). Tourism Malaysia integrated promotion plan 2018-2020. Kuala Lumpur: Tourism Malaysia and Ministry of Tourism and Culture Malaysia.

UKM Report. (1999). Domestic tourism study (Vol. 1). Bangi, Selangor: Universiti Kebangsaan Malaysia, Bureau of Consultancy.

Zikmund, W. G., \& Babib, B. J. (2010). Essentials of marketing research: (South-Western Cengage Learning. ed.). USA: SouthWestern Cengage Learning. 